\title{
ONLINE TEACHING AND GRADING DURING THE COVID-19 PANDEMIC - ATTITUDES OF CROATIAN STUDENTS
}

\author{
MAJA RUŽIĆ-BAF \\ Faculty of Educational Sciences, University Juraj Dobrila of Pula \\ I. M. Ronjgova 1, 52100 Pula, Croatia \\ E-mail: mruzic@unipu.hr \\ ORCID: https://orcid.org/0000-0002-0155-4617 \\ SANDRA KADUM \\ Faculty of Educational Sciences, University Juraj Dobrila of Pula \\ I. M. Ronjgova 1, 52100 Pula, Croatia \\ E-mail: skadum@unipu.hr \\ ORCID: https://orcid.org/0000-0002-8441-0896

\section{KATARINA KVARANTA} \\ Faculty of Educational Sciences, University Juraj Dobrila of Pula \\ I. M. Ronjgova 1, 52100 Pula, Croatia \\ E-mail: kvaranta.katarina@gmail.com \\ ORCID: https://orcid.org/0000-0003-3860-8217
}

\begin{abstract}
Aim. Extraordinary circumstances of the COVID-19 pandemic have led to new ways of learning and teaching, with students and teachers facing many challenges. The aim of the research was to examine attitudes and to determine the impressions and experiences of respondents regarding online teaching as well as to investigate and evaluate learning goals with regard to the SARS-COV-2 virus pandemic.

Methods. The research was conducted in the Republic of Croatia on a sample of 1533 university students. A survey questionnaire designed specifically for the purposes of this research was used. Consisted of three independent variables and ten dependent variables related to online teaching.

Results. The data obtained show that in online teaching, the respondents mostly used programs such as Zoom, Microsoft Teams and Merlin, while the least of them used Skype. Regarding testing and assessment, i.e. the grading of success in online teaching, respondents stated that teachers had mostly used colloquia $(20.6 \%)$ and written exams (19.8\%) for grading, while live exams had been used the least. The largest number of research participants, $61.9 \%$ of them, expressed the opinion that the criteria and grading procedures were clear and published before individual teaching units.
\end{abstract}


Conclusion. Faculties should design different syllabuses for conducting online classes. Centres should be provided/established with the task of collecting digital teaching materials, processing, and storing them, and making them available to teachers and students.

Key words: digital teaching material, online environment, organisation of online teaching, testing and assessment, the Internet

\section{INTRODUCTION}

U nexpected situations of the "new normal" affected all spheres of human activity. Almost overnight, new adjustments took place in all areas of our lives. It was necessary to act quickly, wisely and efficiently in order for the systems to continue to function, primarily for the purpose of preserving the health of the individual, the economy, but also education. New information and communication technologies greatly helped to ensure that classes were held at all levels and that pupils and students were not deprived of their education.

The situation caused by the COVID-19 pandemic has changed. Online education at universities has become the primary form of learning.

Universities around the world have rapidly developed proposals to provide e-learning courses to both university professors and students. Due to this, in recent years there has been a massive spread of online courses open to the general public known as Massive Open Online Courses (MOOC) (MangotiniRossi, 2020; Wong et al., 2019; Yuan \& Powell, 2013).

In the Cambridge dictionary, e-learning is defined as learning done by studying at home, using computers and courses provided on the Internet. Vladimir Šimović and Maja Ružić-Baf (2013) state that electronic or virtual education (and learning) is a broader term that implies any form of education (and learning) with the help of Information and Communication Technology (ICT) and Information Systems (primarily network). Electronic or virtual education can be considered any educational (study) programme that uses ICT and IS (primarily network) with the aim of teaching/learning.

According to a survey conducted by the European University Association (2020), more than $80 \%$ of higher education institutions have repositories for educational materials, as well as a centre for training teachers on learning and teaching in the digital environment. Ronnie C. Choe et al. (2019) state that their use of video lectures during online teaching can improve student involvement and satisfaction, while learning outcomes remained high. On the other hand, Devanshi Desai et al.(2020) conducted a survey indicating that out of $79.9 \%$ of medical students who actively participated in online classes, $42 \%$ considered the timing of online classes to be inappropriate and not complying with working hours. Furthermore, the difficulties in understanding the presented contents were experienced by $35 \%$ of the research participants. The most common obstacle to online teaching was a poor Internet connection. 
Ngoc Thuy Thi Thai et al. (2020) compared different learning styles such as face-to-face learning, full e-learning, blended learning and flipped classroom. Guided by the success of pupils/students, they concluded that there is a significant positive differential effect on learning performance when learning takes place "live" and in the mode of blended learning. The results of their study indicate that pupils/students have more flexibility regarding teaching time and place during live classes, blended learning and full e-learning, while students learning in a flipped classroom environment display significantly greater positive changes in their self-efficiency.

Magdalena Jelińska and Michał B. Paradowski (2021) conducted a survey in 118 countries on a sample of 1487 respondents, all of whom were teachers in higher education. In this research, one group of teachers was engaged in distance learning; the results indicate that, compared to the other group, they coped more successfully with the challenges of teaching in an online environment. Higher education teachers who previously had experience with online teaching coped more successfully.

Michael Gaebel et al. (2021) conducted a survey that included higher education teachers from 368 higher education institutions in 48 countries within the European High Education Area (EHEA). The data obtained show that the share of higher education institutions offering MOOCs has increased significantly, up to $36 \% .57 \%$ of institutions stated that Digitally Enhanced Learning and Teaching (DELT) is increasingly used by them, mostly through blended learning. $80 \%$ of institutions in total offered education aiming at the acquisition of digital skills, had an organised centred dealing with technical issues, a centre for digital learning and teaching, and online repositories for educational materials.

In the Digital Education Action Plan 2021-2027 (European Commission: DG Education Youth Sport and Culture, 2020), it is stated that the COVID-19 crisis has brought greater awareness regarding the use of technology in education and training and its need for improvement, the adaptation of pedagogies, and the development of digital skills.

\section{ONLINE TEACHING AT UNIVERSITIES IN THE REPUBLIC OF CROATIA}

Due to the epidemiological situation, the Ministry of Science and Education of the Republic of Croatia offered three possible scenarios and models for teaching: "live" teaching, mixed teaching (i.e. a hybrid model of teaching) distance teaching, conducted entirely online. The action plan for the implementation of distance learning (Ministry of Science and Education, 2020) states that all three scenarios of teaching have some form of e-learning in their crosssection because the model of distance learning can be implemented simultaneously with the model requiring physical presence in schools, while on the other hand, it is possible to use e-learning in teaching mostly conducted live. 
In accordance with the above scenarios and models of teaching, the Ministry of Science and Education of the Republic of Croatia (2020) developed very detailed instructions relating to assessment and grading during distance learning which are intended for teachers, professors, partly for parents/guardians, but also for students. According to the instructions of the Ministry of Science and Education (2020) for higher education, the emphasis is placed on important content and the use of those assessment methods that are related to the given learning outcomes of each subject. Given that the student is at the centre of the learning and teaching process (in the constructivist approach to learning and teaching), it is important that professors focus on planned educational outcomes, i.e. that the student is active and achieves the set learning outcomes through individual strategies and ways of learning.

Testing and grading of achievements/knowledge are part of the educational process. By testing knowledge, information on the understanding and the acquisition of teaching contents are collected, while grading assesses the pupils/student's achievement (Kadum-Bošnjak et al., 2014). Therefore, testing serves to determine the level of learning outcomes obtained, i.e. the achievement of teaching tasks. It determines the extent and intensity of the acquired knowledge, the degree of the development of working abilities and the adopted educational values (Kadum-Bošnjak, 2013; S. Kadum \& V. Kadum, 2019). Finally, grading is defined as a procedure that monitors the educational development of a pupil/student and determines the level s/he achieved in this regard. It is an agreed method of recording development and achievements in teaching, and classifying learning outcomes into certain categories in a system of different levels of achievement (Kadum-Bošnjak, 2013).

Starting from 2015, the Croatian Academic and Research Network (2020) has implemented e-School project which aim at the informatisation of the education system. In the project, it is stated that in digitally mature educational institutions, adequate use of ICT contributes to efficient and transparent management, development of digitally competent teachers who are readier to apply innovations in their own pedagogical practices and development of digitally competent pupils/students, readier for further education and more competitive on the labour market.

In their educational work, teachers attend trainings and acquire digital competencies, hence for most teachers, distance learning as well as the use of certain digital tools was not new. Kadum et al. (2020) indicate that out of 133 surveyed higher education professors, 37.7\% completed the education programme for online teaching and $80.4 \%$ expressed interest in professional development in the field of modern educational technology in higher education. 


\section{RESEARCH}

\section{The aim and tasks of research}

This research sought to examine students' attitudes towards online teaching, testing and grading during the COVID-19 pandemic. Therefore, the aim of the research was to determine the impressions, experiences and attitudes of the research participants related to online teaching.

\section{Measuring instrument}

A survey questionnaire designed specifically for the purposes of this research was used. It consisted of three independent variables and ten dependent variables related to online teaching. Regarding the independent variables, eight items were based on multiple selections, three on checkboxes, and three on a Likert-type assessment scale, where study participants opted for one of the offered answers.

The questionnaire was created using the Google Forms tool. The survey was posted in Facebook groups for students throughout the Republic of Croatia and was conducted in January 2021. The code of ethics was fully respected: the respondents were given written instructions on how to fill in the measuring instrument; they were guaranteed anonymity and the possibility of giving up further answers; they were explained that the data obtained by this research will be used exclusively for scientific purposes.

Since the questionnaire was used in the research for the first time, it was necessary to determine its basic metric characteristics. The reliability of the statements on the reliability scale expressed by the Cronbach's alpha coefficient showed that it satisfies Nunnally's and Bernstein's internal consistency criterion of .70.

Namely, the obtained coefficient of internal consistency equalled .76.

\section{Research sample}

The research was conducted on a sample of 1533 students in the Republic of Croatia. The characteristics of the sample with respect to gender are shown in Table 1. It can be noticed that as many as $84.0 \%$ of the participants in the research were male, while only $16.0 \%$ of them were female.

Table 1.

Characteristics of the sample with respect to gender

\begin{tabular}{llllll}
\hline & & Frequency & Percent & $\begin{array}{l}\text { Valid } \\
\text { Percent }\end{array}$ & $\begin{array}{l}\text { Cumulative } \\
\text { Percent }\end{array}$ \\
\hline \multirow{3}{*}{ Valid } & Males & 1287 & 84.0 & 84.0 & 84.0 \\
& Females & 246 & 16.0 & 16.0 & 100.0 \\
& Total & 1533 & 100.0 & 100.0 & \\
\hline
\end{tabular}

Source: own research

97.1\% of research participants study at one of the state faculties or departments, while $2.9 \%$ study at a private faculty. 
Table 2, displaying the characteristics of research participants with respect to the year of study, shows that the largest number of respondents is in the first year of study $(39.7 \%)$, while the lowest number of respondents is in the fifth year of study $(11.8 \%)$.

The following statistical values were obtained with the independent variable of the year of study: arithmetic mean $\mathrm{M}=2.41$, standard deviation $\mathrm{SD}=$ 1.423 , and variance SD2 $=2.025$.

Table 2

Characteristics of the sample with respect to the year of study

\begin{tabular}{clcccc}
\hline \multicolumn{1}{c}{$\begin{array}{c}\text { Year } \\
\text { of study }\end{array}$} & Frequency & Percent & $\begin{array}{c}\text { Valid } \\
\text { Percent }\end{array}$ & $\begin{array}{c}\text { Cumulative } \\
\text { Percent }\end{array}$ \\
\hline \multirow{6}{*}{ Valid } & First & 609 & 39.7 & 39.7 & 39.7 \\
& Second & 254 & 16.6 & 16.6 & 56.3 \\
& Third & 276 & 18.0 & 18.0 & 74.3 \\
& Fourth & 213 & 13.9 & 13.9 & 88.2 \\
& Fifth & 181 & 11.8 & 11.8 & 100.0 \\
& Total & 1533 & 100.0 & 100.0 & \\
\hline
\end{tabular}

Source: own research

We also examined the normality of the distribution of the data obtained in the research. The skewness amounts to .519 , while kurtosis to -1.103 . Since in the normal distribution the values of skewness and kurtosis are zero (which is very rare in the social sciences), a positive value of skewness indicates that most of the results are to the left of the arithmetic mean or among the smaller values. A negative kurtosis value indicates that the data distribution is flatter than the normal distribution, which means that most of the data obtained by the survey are at the edges.

\section{RESULTS AND DISCUSSION}

At the very beginning of the questionnaire, the research participants were asked to determine the number of courses (in their study) that were conducted by applying online teaching. More than four-fifths of the respondents $(84.5 \%)$ stated that online teaching was conducted in all courses, while $13.9 \%$ of respondents claimed that it took place in most courses. Only $1.6 \%$ of them stated that courses were rarely taught online.

The following statistical values were obtained for this item: arithmetic mean (1.17), standard deviation (.416), and variance (.173).

The next part of the questionnaire was related to the platforms used to monitor online teaching and to support the teaching process. The outcomes of online education are primarily an increase in the quality of teaching and placing students at the center of the teaching process (Islam, 2012; Radović et al., 2015). Research participants were given the opportunity to opt for multi- 
ple answers. The obtained answers were as follows: the vast majority of respondents, i.e. 819 of them, stated that they used the Zoom platform in online classes. As many as 744 respondents used the Microsoft Teams platform and a similarly large number, i.e. 667 of the respondents, the Merlin platform. Nearly the same number of study participants used Google Meet (400) and Big Blue Button (398). Among less popular platforms, there was Moodle, used by 286 respondents. Finally, 173 research participants stated that they used the Google Classroom platform in online classes and only 68 of them used the Skype platform. In addition to these platforms, research participants stated that they used other platforms to follow online classes, such as Webinar, Jitsi, LMS, Webex, Omega, Facebook, Adobe Connect, E-learning, Discord, Youtube, Cisco meeting, Notion and Gmail.

Evaluation of the quality of teaching materials (for example, literature, etc.) in a virtual environment as compared to previous didactic materials (obtained at the faculty) was the next section that was given to the research participants to comment on. A Likert-type assessment scale was used here. The largest number of respondents, almost half of them $(48.8 \%)$, stated that the quality of teaching materials was approximately the same compared to previous materials; $20.2 \%$ found the quality to be slightly better, while $14.4 \%$ claimed that the quality was slightly worse. The quality was much better in the opinion of $11.2 \%$ of respondents, while $5.4 \%$ of respondents said that quality was much worse than before the introduction of online teaching.

The next item that the respondents commented on was the possibility of the interaction between the teacher and students in a virtual environment. The highest number of survey participants (32.6\%) stated that teacher-student interaction during online teaching, compared to pre-pandemic college teaching, was of approximately the same quality; $24.8 \%$ thought that the interaction was slightly weaker, and $21.1 \%$ stated that the interaction was slightly better. $11.6 \%$ of respondents stated that the interaction was much worse than before, and $9.8 \%$ of respondents stated that it was much better. The following statistical values were obtained with this item: arithmetic mean $\mathrm{M}=2.93$, standard deviation $\mathrm{SD}=1.146$, while variance $\mathrm{SD}^{2}=1.314$.

Table 3 shows the research results on the availability of teachers for regular consultations.

Table 3

Availability of teachers for regular consultations

\begin{tabular}{llcccc}
\hline & Frequency & Per cent & $\begin{array}{c}\text { Valid } \\
\text { Percent }\end{array}$ & $\begin{array}{c}\text { Cumulative } \\
\text { Percent }\end{array}$ \\
\hline \multirow{5}{*}{ Valid } & Yes, they are available & 593 & 38.7 & 38.7 & 38.7 \\
regularly & No, they are not available & 78 & 5.1 & 5.1 & 43.8 \\
& It depends on the teacher & 862 & 56.2 & 56.2 & 100.0 \\
& 1533 & 100.0 & 100.0 & \\
\hline
\end{tabular}

Source: own research 
Table 3 shows that the largest number of research participants, $56.2 \%$, stated that the availability of teachers for consultations depended on the teacher; $38.7 \%$ pointed out that teachers were regularly available for consultations, while $5.1 \%$ claimed teachers were not available for consultations. Statistical values for this item are: arithmetic mean 2.18, standard deviation .959, and variation .919 .

The next four items in the measuring instrument were related to testing and assessment, i.e. the grading of students' achievements during the COVID-19 pandemic. The impressions, experiences and attitudes of research participants related to grading during online classes were determined.

The first of these four items read: "Name the assessment methods used by teachers during online classes." Research participants were given the opportunity to choose multiple answers. The obtained data are shown in Table 4.

Since the respondents were allowed to choose more answers, the total number of answers was 5822, more than the number of respondents in the research (1533). The majority of respondents (20.6\%) answered that, from all the evaluation methods, teachers mostly used the written colloquia, while $19.8 \%$ of respondents answered that the written exam method was used the most. $16.6 \%$ of the research participants stated that teachers used the online oral exam as an assessment method, while slightly fewer of them $(16.1 \%)$ stated that presentation and report were used for assessment; only $9.2 \%$ of respondents stated that teachers used the live exam assessment method.

Table 4

Assessment methods during online teaching

\begin{tabular}{clcc}
\hline \multicolumn{1}{c}{$\begin{array}{c}\text { Assessment methods } \\
(X)\end{array}$} & $\begin{array}{c}\text { Number of students } \\
(f)\end{array}$ & $\begin{array}{c}\text { Percentage } \\
(\%)\end{array}$ \\
\hline \multirow{6}{*}{ Valid } & Oral exam online & 969 & 16.6 \\
& Written exam & 1151 & 19.8 \\
& Seminar papers & 1028 & 17.7 \\
& Colloquia & 1203 & 20.6 \\
& Live exams & 536 & 9.2 \\
& Presentations and reports & 935 & 16.1 \\
& Total (answers) & 5822 & 100.0 \\
\hline
\end{tabular}

Source: own research

The next item related to testing and assessment referred to the feedback received on the assessment results. $48.8 \%$ of the research participants stated that they regularly received feedback from their teachers on the results of the assessment, while $42.6 \%$ of them answered that it depended on the structure of the course. Only $8.6 \%$ of respondents stated that they did not receive feedback from their teachers on testing and assessment.

The following statement- "Criteria and methods of assessment are clear to me and were published before the start of the implementation of individual teaching units" - was the next item on which the participants of the research expressed their opinion. It used the Likert-type assessment scale, where res- 
pondents opted for one of the offered answers, from $1=$ completely disagree to $5=$ completely agree. The largest number of respondents $(33.1 \%)$ answered that they completely agree with the statement, while $28.8 \%$ of respondents answered that they slightly agree; $23.1 \%$ of the research participants answered that they neither agree nor disagree with the statement. $11.1 \%$ of them slightly disagreed, while $3.9 \%$ of respondents completely disagreed.

The penultimate issue that the research participants commented on was the objectivity and reliability of the grading. The statement read: "The grading of students while studying in a virtual environment is objective and reliable. $\square$ It was possible to choose between the answers I agree, I disagree and I cannot estimate. $35.2 \%$ of respondents were in favour of the "I agree," while $32.1 \%$ were in favour of the "I disagree"; the option "I cannot estimate" was chosen by $32.7 \%$ of study participants.

The last item in the measuring instrument that the research participants commented on was related to (possible) difficulties in following online teaching. The item was formulated as follows: "If you had any difficulties in following online classes, please describe it." Respondents were to choose multiple answers, which is why the total number of answers is 3072, more than the respondents in the sample (1533). The obtained data are shown in Table 5.

The highest number of the survey participants, $24.1 \%$ of them, stated that they had the most difficulties with the Internet; $17.3 \%$ of respondents had difficulties with a large number of independent tasks, while $16.8 \%$ of them had problems with a webcam or microphone. $14.5 \%$ of respondents stated that they could not access the platform and $2.8 \%$ that they had health problems. $2.3 \%$ of the research participants had difficulties related to not having a personal or laptop computer, while $0.1 \%$ experienced a computer malfunction. Lack of concentration and motivation was stated by $0.3 \%$ of survey participants, while $11.2 \%$ of the respondents claimed they had no difficulties at all during online teaching.

Table 5

Difficulties in following online classes

\begin{tabular}{llcc}
\hline \multicolumn{1}{c}{$\begin{array}{c}\text { Difficulties in following online classes } \\
(X)\end{array}$} & $\begin{array}{c}\text { Number of students } \\
(f)\end{array}$ & $\begin{array}{c}\text { Percentage } \\
(\%)\end{array}$ \\
\hline Inability to access the platform & 444 & 14.5 \\
Lack of a personal computer/laptop & 71 & 2.3 \\
Problems with webcam, microphone, etc. & 517 & 16.8 \\
A large number of independent tasks & 536 & 17.3 \\
Communication with the teacher & 324 & 10.6 \\
Valid & 86 & 2.8 \\
Health problems & 740 & 24.1 \\
Problems with the Internet & 2 & 0.1 \\
Computer failure & 9 & 0.3 \\
Lack of concentration and motivation & 343 & 11.2 \\
No difficulties & 3072 & 100.0 \\
Total (answers) &
\end{tabular}

Source: own research 


\section{CONCLUSION}

Extraordinary circumstances have led to new ways of teaching. Students and professors faced many challenges, although most professors had held hybrid classes already and had previously completed some form of education acquiring the digital skills and competencies. The obtained research results showed that, for example, distance learning could be modernised, given that most respondents answered that there was no significant difference in the use of materials given to students for learning during face-to-face and online classes. Consultations should certainly be held regularly, during both face-to-face and distance learning classes. Colloquia were the most common evaluation method, though assessment in the online environment could also be conducted via oral exams. It is certainly positive that the respondents answered that the criteria and methods of grading were clear and published in a timely manner, i.e. before the start of individual teaching units, which in our opinion makes it much easier for students to understand their responsibilities. Although the old famous proverb claims that "grade is not a measure of knowledge," it is still important to most students. Unfortunately, only $35.2 \%$ of students answered that grading was objective and reliable in the online environment, hence the question is what about the other students who disagreed with this statement. We find this claim to be a good starting point for future research.

In the online research conducted in April 2020 (Doolan et al., 2020), which involved 17,116 students and alumni, full-time and part-time students studying at European higher education institutions from 41 European countries, the obtained data indicated that a total of $80.7 \%$ of students felt safe using online platforms such as Microsoft Teams, Zoom and others. Respondents from that study did not fully agree that teachers gave them feedback on completed assignments and online exams in the new pandemic situation. The research results also showed that a total of $89.3 \%$ of students have their own computer, but only $41.0 \%$ confirmed having a quality and good Internet connection. Furthermore, $74.61 \%$ of respondents answered that classes were held in real-time, $44.51 \%$ answered that they received presentations instead of lectures, $20.58 \%$ of them received audio recordings of lectures and $44.51 \%$ video recordings of lectures.

During online classes, students from our research mostly used the following platforms: Zoom, Merlin, Microsoft Teams, Google Meet, and Big Blue Button. The answers provided by respondents indicate that online teaching took place in all or almost all courses.

We were also interested in the quality of teaching materials and the interaction of professors with students. The vast majority of students answered that the quality of teaching materials and interactions with professors were approximately the same as at the faculty. The responses to the question of whether teachers were regularly available during consultations caused a slight surprise because as many as $56.2 \%$ of students wrote that it depended on the professor and $5.1 \%$ of students answered that professors were not ava- 
ilable. We expected better results in terms of consultations because there are certain emergencies when all that can be done is to communicate online. The assessment methods that teachers mostly used during online classes were: written exams, colloquia, seminar papers, presentations and reports, oral exams and face-to-face exams. Students were satisfied regarding feedback on grading and information on criteria and methods of grading, though they had diverse opinions whether the grading was objective and reliable: $35.2 \%$ agreed that the grading was objective and reliable, $32.7 \%$ disagreed with the statement, while $32.1 \%$ did not have an opinion. The last issue we were interested in were the difficulties experienced during online classes. Students had the most difficulties with the Internet, independent assignments, lack of access to platforms and lack of communication with professors.

We suggest that all faculties, both private and public, should design completely different syllabi for distance learning; open centres within the faculty whose task is to support teachers and students during online classes; establish centres to collect, process and store digital materials and make them available to teachers and students; design a network of digital material repositories between universities in the Republic of Croatia and other universities in EU.

The Digital Education Action Plan (2021-2027) of the EU (European Commission: DG Education Youth Sport and Culture, 2020) sets out the key principles of adapting to digital transformation in order to improve quality and inclusiveness. "The following guiding principles are essential to ensure that education and training are adjusted to the digital transformation and further improve the quality and inclusiveness of education in Europe:

1. High quality and inclusive digital education, which respects the protection of personal data and ethics, needs to be a strategic goal of all bodies and agencies active in education and training

2. Transforming education for the digital age is a task for the whole society.

3. Appropriate investment in connectivity, equipment and organisational capacity and skills should ensure that everybody has access to digital education.

4. Digital education should play a pivotal role in increasing equality and inclusiveness.

5. Digital competence should be a core skill for all educators and training staff

6. Education leaders play a key role in digital education

7. Digital literacy is essential for life in a digitalised world.

8. Basic digital skills

9. Advanced digital skills

10. Need for high-quality education content to boost the relevance, quality and inclusiveness of European education and training at all levels" (European Commission, 2020, pp. 8-9). 


\section{ACKNOWLEDGMENT}

The paper was created as part of the institutional project Docimology Issues in Teaching and was approved by the Faculty of Educational Sciences, Juraj Dobrila University of Pula.

\section{REFERENCES}

[1] AZVO (2020). Izazovi u visokom obrazovanju za vrijeme pandemije bolesti COVID-19 $i$ socijalne izolacije: iskustva i potrebe studenata $i$ djelatnika visokih učilišta [Challenges in higher education during the pandemic of COVID-19 disease and social isolation: Experiences and needs of students and staff of higher education institutions]. Retrieved from https://www.azvo.hr/ images/stories/novosti/Rezultati_istra\%C5\%BEivanja_Izazovi_u_visokom_obrazovanju_ za_vrijeme_pandemije_bolesti_COVID19_i_socijalne_izolacije.pdf

[2] Cambridge Dictionary (n.d.). E-learning. In Cambridge Dictionary Online.

[3] Croatian Academic and Research Network (Carnet) (2020). Projekt e-skole [E-school project]. Retrieved from https://pilot.e-skole.hr/hr/e-skole/opis-projekta/.

[4] Choe, R. C., Scuric, Z., Eshkol, E., Cruser, S., Arndt, A., Cox, R., Toma, S.P., Shapiro, C., Levis-Fitzgerald, M., Barnes, G., \& Crosbie, R. H. (2019). Student satisfaction and learning outcomes in asynchronous online lecture videos. CBE Life Sciences Education, 18(4). https:// doi.org/10.1187/cbe.18-08-0171

[5] Desai, D., Sen, S., Desai, S., Desai, R., \& Dash, S. (2020). Assessment of online teaching as an adjunct to medical education in the backdrop of COVID-19 lockdown in a developing country - An online survey. Indian Journal of Ophthalmology, 68(11), 2399-2403. https://doi. org/10.4103/ijo.IJO_2049_20

[6] Doolan, K., Barada, V., Burić, I., Krolo, K., Tonković, Ž. (2020). Student life during the COVID - 19 pandemic lockdown: Europe-wide insights. Retrieved from http:/ / www.ehea.info/Upload/ BFUG_DE_UK_73_11_6_students_Covid_19_survey_results.pdfUn

[7] European Commission: DG Education Youth Sport and Culture (2020). Digital education action plan 2021-2027, Resetting education and training for the digital age. Retrieved from https:/ / ec.europa.eu/education/sites/default/files/document-library-docs/deapcommunication-sept2020_en.pdf

[8] European University Association (2020). European higher education in the Covid-19 crisis. Retrieved from https://eua.eu/downloads/publications/briefing_european\%20higher\%20education \% 20in \% 20the\%20covid-19\%20crisis.pdf, European higher education in the Covid-19.

[9] Gaebel, M., Zhang, T., Stoeber, H., \& Morrisroe, A. (2021). Digitally enhanced learning and teaching in European higher education institutions. Retrieved from https://eua.eu/downloads/publications/digi-he\%20survey\%20report.pdf

[10] Islam, N. (2012). The role of perceived system quality as the educators' motivation to continue e-learning system use. AIS Transaction of Human-computer Interaction, 4(1), 25-44.

[11] Jelińska, M., \& Paradowski, M. B. (2021). Teachers' engagement in and coping with emergency remote instruction during COVID-19-induced school closures: A multinational contextual perspective. Online Learning Journal, 25(1), 303-328. https:// doi.org/10.24059/olj.v25i1.2492

[12] Kadum, S., Ružić-Baf, M., \& Dumančić, M. (2020). Contemporary educational technology and teaching media in higher education teaching during the COVID-19 pandemic. In L. Gómez Chova, A. López Martínez \& I. Candel Torres (Eds.), 13th International Conference of Education, Research and Innovation (pp.1303-1313). IATED.

[13] Kadum-Bošnjak, S. (2013). Dokimologija u primarnom obrazovanju [Docimology in primary education]. Pula: Sveučilište Jurja Dobrile u Puli, Odjel za odgojne i obrazovne znanosti.

[14] Kadum, S., Cotič, M., \& Felda, D. (2014). Činitelji uspješnosti nastave u primarnom obrazovanju [Factors of teaching success in primary education]. Koper: Univerzana Primorskem, Pedagoška fakulteta.

[15] Kadum, S., \& Kadum, V. (2019). Poglavlja iz didaktike matematike [Chapters from the didactis of mathematics]. Zagreb: Element d.o.o. 
[16] Katavić, I. (2015). Online učenje:jeftiniji i jednostavniji način za stjecanje novih znanja i vještina [Online learning: A cheaper and easier way to acquire new knowledge and skills]. Retrieved from https://lider.media/znanja/online-ucenje-jeftiniji-i-jednostavniji-nacin-za-stjecanje-novih -znanja-i-vjestina/

[17] Margottini, M., \& Rossi, F. (2020). Processi autoregolativi e feedback nell'apprendimento online [Self-regulation processes and feedback in online learning]. Journal of Educational, Cultural and Psychological Studies, 20, 193-209. https:// dx.doi.org/10.7358/ecps-2020-021-marg

[18] Ministarstvo znanosti i obrazovanja (2020). Akcijski plan provedbe nastave na daljinu [Distance learning implementation action plan]. Retrieved from https://mzo.gov.hr/UserDocs Images// dokumenti/Obrazovanje/NastavaNaDaljinu//Akcijski\%20plan\%20za\%20provedbu $\% 20$ nastave $\% 20$ na $\% 20$ daljinu $\% 20-\% 20$ Model $\% 20$ nastave $\% 20$ na $\% 20$ daljinu.pdf

[19] Ministarstvo znanosti i obrazovanja (2020). Upute za vrednovanje i ocjenjivanje tijekom nastave na daljinu [Instructions for evaluation and grading during distance learning]. Retrieved from https://mzo.gov.hr/UserDocsImages/dokumenti/Obrazovanje/Upute-zavrednovanje/Upute \%20za \%20vrednovanje $\% 20$ i $\% 20$ ocjenjivanje $\% 20$ tijekom $\% 20$ nastave $\% 20$ na\%20daljinu.pdf

[20] Radović S., Marić M., \& Golubović Lj. (2015). Mogućnosti upotrebe IKT-a i platforme eZbirka u nastavnim aktivnostim. In A. Mihajlović (Ed.), 3. internacionalna konferencija Metodički aspekti nastave matematike (pp. 249-257). Fakultet pedagoških nauka univerziteta u Kragujevcu.

[21] Šimović, V., \& Ružić-Baf, M. (2013). Contemporary information system. Pula: University Juraj Dobrila.

[22] Thai, N. T. T., De Wever, B., \& Valcke, M. (2020). Face-to-face, blended, flipped, or online learning environment? Impact on learning performance and student cognitions. Computer Assist Learn, 36, 397- 411. https://doi.org/10.1111/jcal.12423

[23] Wong, J., Baars, M., Davis, D., Van Der Zee, T., Houben, G. J., \& Paas, F. (2019). Supporting self-regulated learning in online learning environments and MOOCs: A systematic review. International Journal of Human-Computer Interaction, 35(4-5), 356-373.

[24] Zenović, I., \& Bagarić. I. (2014). Trendovi u otvorenom učenju na daljinu u svetu i kod nas [Trends in open distance learning in the world and in our country]. Sinteza: Internet and Education, 379-384. Retrieved from http:/ / portal.sinteza.singidunum.ac.rs/Media/files/2014/379384.pdf 